\title{
The Role of Uncomfortable Heritage in Sustainable Development
}

Bushra Nabas

\begin{abstract}
This research examines the concept of uncomfortable heritage sites, and analyse how sustainable development can be attained through utilising adaptive reuse for sites associated with atrocious events.

The research starts with a thorough analysis of key issues; uncomfortable heritage and its cultural significance, heritage adaptive reuse, and last but not least, sustainable development. Three aspects of sustainability were chosen for this study; environmental, economic and most importantly cultural sustainability.

The resulted research created a framework in which an application of comparative analyses between the cases were employed, which are Haus des Meeres in Vienna, The Energy Bunker in Hamburg and Boros Collection in Berlin.

The research concluded that adaptive reuse of uncomfortable heritage contributed to the sustainable development in various ways; however, due to the sensitivity of this type of heritage, it is very important to conduct a comprehensive analysis on the site before adaptively reusing it.
\end{abstract}

\section{Keywords:}

uncomfortable heritage, third reich relics, adaptive reuse, sustainable development, environmental sustainability, economic sustainability, cultural sustainability.

\section{Introduction}

Cultural continuity is fostered by heritage, which is what contemporary society decides to inherit and pass on to future generations. Therefore, for a long period of time, historic properties were automatically considered as pleasing objects, hence it is enticing to assume that the concept of heritage is always brimful with positive associations. ${ }^{1}$ However, a shift in the perspective of heritage occurred fairly recently, when not only the constructive and positive are observed as worth preserving; negative sites and events that are related to acts of atrocities, cruelties and utmost futility are increasingly considered as "heritage". ${ }^{2}$

Therefore, according to Feversham and Schmidt, ${ }^{3}$ dealing with the unpleasantness and shameful evidences of history, and with events and sites that generate discomfort is a reflection of the maturity and responsibility of any society. Thus these evidences, events and sites are increasingly being considered as 'heritage'. ${ }^{4}$

Nevertheless, the paradox of willingly considering the destructive and cruel side of history as aspects to be represented and protected for future generations is what makes dealing with such heritage a complicated process.

Consequently, this research aims to investigate this understudied and essential type of heritage, and how -if utilised properly through adaptive reuse- it can majorly contribute to the sustainable development of a society in three chosen aspects; environmental, economic and cultural, while of course retaining the cultural significance of uncomfortable heritage sites.

\footnotetext{
${ }^{1}$ Kristian Kristiansen, "Perspectives on the archaeological heritage: history and future." (Archaeological Heritage Management in the Modern World 9, 1989), 23-29; Georg Mörsch. “Aufgeklärter Widerstand.” (Das Denkmal als Frage und Aufgabe, Basel ,1989), 115-119; Wendi Field Murray, et al. “The remaking of Lake Sakakawea: Locating cultural viability in negative heritage on the Missouri River." (American ethnologist 38, 2011), 468-483; Leo Schmidt. "Architectural conservation: an introduction." (2008); John E. Tunbridge, and Gregory John Ashworth. "Dissonant heritage: the management of the past as a resource in conflict." (John Wiley \& Sons, 1996).

${ }^{2}$ William Logan, and Keir Reeves, eds. "Places of pain and shame: dealing with difficult heritage". (Routledge, 2008) 1-5; Schmidt. “Architectural conservaion"

${ }^{3}$ Polly Feversham, and Leo Schmidt. "The Berlin Wall Today. Cultural Significance and Conservation Issues." Berlin: Verlag Bauwesen (1999), 140

${ }^{4}$ Logan and Reeves, eds. "Places of pain and shame", 1-5.
} 


\section{Research Question}

How can uncomfortable heritage contribute positively to the sustainable development through adaptive reuse?

\section{Research Objective}

The main objective of this research attempts to contribute to the growing body of research in understanding the importance of Uncomfortable Heritage as well as to contribute in directing the future of Adaptive Reuse as an influential tool for utilising structures related to uncomfortable past to attain sustainable development.

\section{Research Methodology}

The research took on a qualitative approach, since it focuses on explanation and interpretation rather than quantification, ${ }^{5}$ and is concerned with developing an understanding of social phenomena, ${ }^{6}$ which in this research is the adaptive reuse of uncomfortable heritage sites.

Another important reason for the adoption of a qualitative approach rather than a quantitative, is that this research does not aim to present statistical or numerical data or evaluate theories, which all can be achieved by a quantitative approach; ${ }^{7}$ on the contrary, the research attempts to investigate the possibility of sustainable development through adaptive reuse of uncomfortable heritage, which was achieved by a thorough research in the academic field at first, followed by an analysis of contemporary case studies.

\section{Data Collection}

The data collection method adopted in this research was secondary data obtained from the academic researches for the theoretical part of the research, which allowed for a much larger database to analyse and comprehend. As for the case study analysis, a methodological pluralism approach was adopted, a combination of secondary and primary data were obtained and analysed. The secondary data were acquired by an intensive academic research on the history, previous and current function, the cultural significance and layers that contributed to the significance. The primary data were obtained through direct observations by the author during a site visit, in addition to an on-site interview.

The process of selecting which cases exactly to choose was predominantly shaped by a framework of several aspects concluded from the theoretical part of the research. Accordingly, three cases were analysed in order to cover a wider spectrum of adaptive reuse practices.

\section{Theoretical Analysis}

Academic research in the field of heritage related to atrocities and unpleasantness is in its infancy stages, yet it has widely debated history. ${ }^{8}$ Sensitive sites are vastly discussed in the existing academic and theoretical literature from a dark tourism perspective, which is defined as 'tourist activities at sensitive sites', hence the focus is mainly on different aspects related to tourism, namely; investigating visitor motivation and determining whether dark tourism is demand or supply driven. ${ }^{9}$

Therefore, substantial literature regarding Uncomfortable Heritage and Sustainable Development, in addition to literature in the sub-fields that consider applicable theoretical approaches such as the literature in Dark Tourism and Heritage Adaptive Reuse were investigated.

\section{Uncomfortable Heritage}

This emerging category of heritage is discussed by various scholars under different idioms with subtle nuances. The scholars articulated this heritage with synonymous terms such as Uncomfortable, Dark, Difficult, Dissonant and Negative.

\footnotetext{
${ }^{5}$ Catherine Cassell, "Qualitative methods in organizational research: A practical guide". (Sage Publications Ltd, 1994), 912.

${ }^{6}$ Stephen Kwadwo Antwi, and Kasim Hamza. "Qualitative and quantitative research paradigms in business research: A philosophical reflection" (European Journal of Business and Management 7, no. 3 2015): 217-225.

${ }^{7}$ Stephen Kwadwo Antwi, and Kasim Hamza. "Qualitative and quantitative research paradigms in business research: A philosophical reflection"

${ }^{8}$ Logan and Reeves, eds. "Places of pain and shame" 1-5; Laura McAtackney. "An Archaeology of the Troubles: the dark heritage ofLong Kesh/Maze prison". (OUP Oxford, 2014).

${ }^{9}$ Philip Stone and Richard Sharpley, "Consuming dark tourism: A thanatological perspective” (Annals of tourism Research 35, no. 2 , 2008): 575.
} 
The term Uncomfortable Heritage was defined by Sam Merrill as "heritage that is associated either directly or indirectly with human death, pain and/or suffering, whether explicitly embodied in tangible sites or implicitly contained within periods of a site's history". ${ }^{10}$ Dark Heritage is a corresponding terminology that was described by McAtackney for historical sites with links to death and destruction. ${ }^{11}$

Further, comparable jargons were addressed by others, such as the term Negative Heritage which was defined by Meskell as "a site associated with conflictual background, and became the repository of negative memory in the collective imaginary". ${ }^{12}$

In addition, the term Difficult Heritage was broadly adopted by Logan and Reeves as "a reflection of the destructive and brutal sideofhistory". 13

Considering that the idioms are somehow synonymous, for the purpose of this research, the term Uncomfortable Heritage is employed throughout the research as it approximately comprehends all inconvenient aspects of history.

\section{Cultural Significance of Uncomfortable Heritage}

Most societies at some point of their history had some form of an involvement in an unresting circumstances, whether it was a civil disorder, wars or connections to a belief system or a political ideology that was based on discrimination, intolerance or hostilities. ${ }^{14}$ Thus, disregarding those aspects of history and choosing the more pleasant ones is surely inexplicable, as we have to confront those uncomfortable memories, since dealing with the unpleasantness and shameful evidences of history, and with events and sites that generate discomfort is a reflection of the maturity and responsibility of any society. ${ }^{15}$

\section{Categories and Classifications}

As mentioned above, sensitive sites are vastly discussed in the existing academic and theoretical literature from a dark tourism perspective, therefore studying the categorisation of uncomfortable sites according to their touristic attributes can provide researchers with a general understanding of the factors that affect the significance of the uncomfortable layer in the heritage sites.

One of the most comprehensive categorisations is by Stone, ${ }^{16}$ as outlined in (Figure 1), which demonstrates possible typologies that are described in terms of a spectrum relating to shades of darkness, those typologies are based on "various defining characteristics, perceptions and product features". ${ }^{17}$

For the purpose of this research, the following factors are taken into consideration when selecting and analysing the adaptive reuse of the case studies:

- Chronological dimension.

- Political ideology.

- Location.

\section{Dealing with Uncomfortable Heritage}

It is established by several scholars that dealing with uncomfortable heritage and safeguarding unpleasant memories is not a straightforward process since the obvious rule is that whatever is unpopular and unloved is exceptionally vulnerable. ${ }^{18}$

Therefore, uncomfortable heritage has been treated in fairly predictable ways, such as with silence, neglect and in severe cases, destruction and removal in an intentional policy of collective amnesia, with the hope that this will lead to healing and forgetting

\footnotetext{
${ }_{10}$ Sam Merrill "Determining Darkness: The Influence Of Function, Necessity \& Scale On The Memorialisation Of Sensitive Sites". In A Reader In Uncomfortable Heritage And Dark Tourism, , edited by Sam Merrill and Leo Schmidt. (Cottbus: BTU Cottbus, 2010): 155, http://www-docs.tu-cottbus. de/denkmalpflege/public/downloads/UHDT_Reader.pdf

${ }^{11}$ McAtackney, “An Archaeology of the Troubles”, 165-180.

${ }^{12}$ Lynn Meskell, "Negative heritage and past mastering in archaeology”. (Anthropological quarterly 75, no. 3 ,2002): 558.

${ }^{13}$ Logan and Reeves, eds. "Places of pain and shame" 1-5.

${ }^{14}$ Logan and Reeves, eds. "Places of pain and shame"

${ }^{15}$ Feversham and Schmidt, "The Berlin Wall Today" 140; Schmidt, "Architectural conservaion", 112.

${ }^{16}$ Philip Stone, “A dark tourism spectrum: Towards a typology of death and macabre related tourist sites, attractions and exhibitions” (Turizam: međunarodni znanstveno-stručni časopis 54, no. 2,2006$), 145-160$.

${ }^{17}$ Stone, “A dark tourism spectrum, 146.

${ }^{18}$ Schmidt, “Architectural conservaion”, 111.
} 
thetragicevents. ${ }^{19}$

Scholars have identified five different general methods of dealing with 'heritage that hurts' in sites of grief and adversity:

1. Ignoring;

2. Erasing;

3. Celebrating;

4. Transmuting or 'adaptive reuse';

5. Commemorating.

It is worth mentioning that none is completely effective, yet all have some advisability. ${ }^{20}$

Research has tended to focus on commemoration and memorialisation or even ignoring and erasing uncomfortable memories as a reconciliation method rather than utilising the existing structures to benefit the communities and future generations. Thus, adaptive reuse is thoroughly discussed in the heritage academic research as a method of heritage conservation and preservation for the cultural significance of a specific structure; however, to date there has been limited research that has examined the role of adaptive reuse in utilising uncomfortable heritage to attain sustainable development.

The reason behind that might be that buildings are fragile carriers of memories compared to sculptures, yet they embody political ideas in their form. ${ }^{21}$ Therefore transforming them into new uses can be an indistinct process.

\section{Adaptive Reuse of Uncomfortable Heritage}

The term 'Adaptive Reuse' is defined variously among scholars and heritage organisations, it is broadly interpreted with terms indicating the 'change of use' such as renovation, remodelling, rehabilitation, refurbishment and recycling. ${ }^{22}$

It can be defined as "conserving structurally sound heritage buildings by converting the use of them in order to retain their cultural significance, in addition to other objectives such as to improve the environmental, social and financial performance of the heritage buildings". ${ }^{23}$ Converting the use might require changes in the structural system, fabric and material. Therefore, a successful adaptive reuse project should respect and retain the cultural significance and add a distinguishable contemporary layer.

From the previous definition, we can observe that advantages of adaptive reuse for heritage in general and uncomfortable heritage in particular are multitudinous. Firstly, adaptive reuse is an essential element of conservation; by connecting and interacting with heritage, cultural identity can be constantly reified, and this enables the heritage assets to have continuing social relevance in addition to the continuing use. ${ }^{24}$

Furthermore, it is needless to say that once buildings are constructed, the value of the building fabric as a material resources is too worthy to be neglected, therefore, adaptive reuse can help transform unutilised heritage assets into accessible and functional places and avoid the creation of demolition waste, therefore, regenerating the community in a sustainable manner, which will raise the value of the building, in addition to helping communities, developers as well as governments to reduce the costs of continued urban expansion; whether environmental, economic or social. ${ }^{25}$

\footnotetext{
${ }^{19}$ Gregory J. Ashworth, . "Heritage, tourism and Europe: a European future for a European past." (Heritage, tourism and society , 1995): 68-84; Gilly Carr, and Keir Reeves, eds. "Heritage and Memory of War: Responses from Small Islands". (Vol. 9. Routledge, 2015); Anjah Merbach. «Removing Uncomfortable Heritage, its Meaning and Consequence: The Fall of Political Public Monuments in the Former GDR». In A Reader In Uncomfortable Heritage And Dark Tourism, edited by Sam Merrill and Leo Schmidt. (Cottbus: BTU Cottbus, 2010): 280, http://www-docs.tu-cottbus.de/denkmalpflege/public/ downloads/UHDT_Reader.pdf

${ }^{20}$ David Lowenthal, "Tragic traces on the Rhodian shore." (Historic Environment 17, no. 1,2003): 4-6

${ }^{21}$ Tim Benton, ed. “Understanding heritage and memory.” (Manchester University, 2010).

${ }^{22}$ Sara J. Wilkinson, Kimberley James, and Richard Reed. "Using building adaptation to deliver sustainability in Australia" (Structural Survey 27, no. 1 , 2009): 46-61.

${ }^{23}$ Peter A. Bullen, “Adaptive reuse and sustainability of commercial buildings.” (Facilities 25, no. 1/2 , 2007): 20-31; Peter A. Bullen, and Peter ED Love, “Adaptive reuse of heritage buildings." (Structural Survey 29, no. 5, 2011): 411-421; Craig Langston, Francis KW Wong, Eddie CM Hui, and Li-Yin Shen. "Strategic assessment of building adaptive reuse opportunities in Hong Kong." (Building and Environment 43, no. 10, 2008): 1709-1718.

${ }^{24}$ Wendi Field Murray, María Nieves Zedeño, Kacy L. Hollenback, and Calvin Grinnell. "The remaking of Lake Sakakawea: Locating cultural viability in negative heritage on the Missouri River." (American ethnologist 38, no. 3, 2011): 468-483.

${ }_{25}$ Rick Ball, "Developers, regeneration and sustainability issues in the reuse of vacant industrial buildings." (Building Research \& Information 27, no. 3 , 1999): 140-148; Bullen, and ED Love. "The rhetoric of adaptive reuse or reality of demolition: Views from the field." (Cities 27, no. 4, 2010): 215-224; Bullen, and Love. "Adaptive reuse of heritage buildings." ; Langston, Wong, Hui, and Shen. "Strategic assessment of building adaptive reuse" 1709-1718; Wilkinson, James, Reed. "Using building" 46-61; Schmidt. "Architectural conservaion"; Esther HK Yung, and Edwin HW Chan. "Implementation challenges to the adaptive reuse of heritage buildings: Towards the goals of sustainable, low carbon cities.” (Habitat International 36, no. 3, 2012): 1712
} 
Nonetheless, uncomfortable heritage can be a delicate and sensitive issue to handle, therefore, reusing sites with relationships to atrocious events and human suffering can be an intricate process.

Sam Merril described three interconnected variables that influence the memorialisation of uncomfortable events; which are function, necessity and scale. ${ }^{26}$

The variable of 'function' expounds the distinction between the original function of the uncomfortable site before the atrocious event and the new function following the event. It is worth mentioning that the original function does not have to be a negative one. ${ }^{27}$

This variable is consequentially synonymous to the adaptive reuse concept. However, the other two variables evidently affect the new function and determine what an acceptable function that can be adopted is. ${ }^{28}$

'Necessity' is the second variable, which demonstrates the need of the society, whether to continue or change the original function of the uncomfortable site. This variable reflects the need to remember or forget the atrocious events, in addition, it depends on several factors such as economical, social or even logistical and infrastructural, and therefore, this variable is dynamic and changes with time. ${ }^{29}$

The third variable; 'scale' discusses the concept of the degree of destruction, loss and trauma, which might affect the continuation or the change of the function. ${ }^{30}$

\section{Sustainable Development}

The term "Sustainable development" has been defined by scholars in many ways, and is a widely used concept, therefore it causes many different responses, ${ }^{31}$ depending on the point of view of the definer; whether it is from a business point of view; governmental; social reformers or environmental activists, all of which put their own interpretations on what sustainable development refers to. ${ }^{32}$

One of the most comprehensive definitions by Brundtland is as follows:

"Meeting the needs of the present without compromising the ability of future generations to meet their own needs... A process of change in which the exploitation of resources, the direction of investments, the orientation of technological development, and institutional change are all in harmony and enhance both current and future potential to meet human needs and aspirations". ${ }^{33}$

\section{The Relation between the Concept of Uncomfortable Heritage and the Concept of Sustainability}

As aforementioned, the concept of Uncomfortable Heritage covers the inconvenient aspects of human history; however, such atrocious and painful events are not easily recognised within the society, let alone are sustained for future generations, nonetheless, due to the immense importance of Uncomfortable Heritage for the collective memory of mankind, a link between the two concepts is of vital importance.

The relationship stems from the definition of Sustainable Development, which summarizes the process of sustainably developing Uncomfortable Heritage as the process where:

- The exploitation of resources,

- The direction of investments,

\footnotetext{
${ }^{26}$ Merrill, «Determining Darkness”, 152-174.

${ }^{27}$ Merrill, «Determining Darkness”, 152-174.

${ }^{28}$ Merrill, “Determining Darkness", 152-174.

${ }^{29}$ Merrill, “Determining Darkness”, 152-174.

${ }^{30}$ Merrill, “Determining Darkness", 152-174.

${ }^{31}$ Bill Hopwood, Mary Mellor, and Geoff O-Brien. "Sustainable development: mapping different approaches." (Sustainable development 13, no. 1, 2005): $38-52$.

${ }^{32}$ Bob Giddings, Bill Hopwood, and Geoff O'brien. "Environment, economy and society: fitting them together into sustainable development" (Sustainable development 10, no. 4, 2002): 187-196.

${ }^{33}$ Gro Harlem Brundtland, "Our common future-Call for action“" (Environmental Conservation 14, no. 4, 1987): 291-294.
} 
- The orientation of technological development,

- The institutional change.

are all in harmony and enhance both current and future potential to meet human needs and aspirations". ${ }^{34}$

Therefore, transitioning towards attaining sustainable development will demand changes in human behaviour, values and attitudes in order to meet human needs; this means changes with the methods of dealing with Uncomfortable Heritage will transpire in order to meet the needs of the present without compromising the ability of the future generations to meet their own needs. ${ }^{35}$

Accordingly, we can reflect the main concept of sustainable development on the three chosen aspects for this research paper:

- Environmental Sustainability: how can buildings and monuments with uncomfortable past be adaptively reused to attain environmental sustainability?

- Economic Sustainability: will adaptive reuse of uncomfortable heritage achieve economic sustainability that will benefit the present and future sustainability without jeopardising the authenticity and integrity of the site?

- Cultural Sustainability: building on economic sustainability; can cultural values and importance of uncomfortable heritage be sustained and protected through adaptive reuse?

In the next section of this research, three case studies will illustrate how the three aspects of sustainability are achieved on different degrees.

\section{Case Studies}

The chosen case studies are Flak towers and bunkers from the World War II period, constructed by the Nazi Regime between 1940-1945 for military-related purposes as well as air-raid shelters. (Figure 2)

The cases are:

- Haus des Meeres in Vienna.

- The Energy Bunker in Hamburg.

- Boros Collection of Contemporary Art in Berlin.

They were considered as places of oppression and cruelty for several reasons, namely; their construction from reinforced concrete by forced labour from prisoners of war; using teenage youngsters and old men as gun controllers and helpers for the Luftwaffe; racial and ethnic exclusion for groups who were not allowed to enter the bunkers in war times. ${ }^{36}$

After World War II, as sites associated with atrocious events and unpleasant memories, flak towers and bunkers were dealt with in predictable ways; demolition, forgetting/ignoring or normalisation. ${ }^{37}$

Notwithstanding that all three cases represent obvious tangible relics of the Third Reich era, in addition to the sentimental values attached to them; their main cultural significance lies in being an imperative component of our history as mankind, a history that cannot be changed, only confronted and benefited from. Hence they represent an indispensable contribution to the collective memory of humankind, in addition, they enthral us to inspect our values, study our history and help us approach the challenges of the future by accepting all the unpleasant and uncomfortable aspects of the Second World War period. Furthermore, they provide us with an opportunity to develop our wisdom.

The process of selecting the cases was predominantly shaped by a framework of intertwined aspects; namely, the three variables described by Merrill: ${ }^{38}$ function, necessity and scale in addition to:

- Chronological dimension

- Political ideology

- Location

Analysing them comparatively however, was according to the principles of the Burra Charter and the general guidelines of heritage adaptive reuse.

The cases share similarities regarding the chosen variables and factors, which facilitated a more attentive research on the

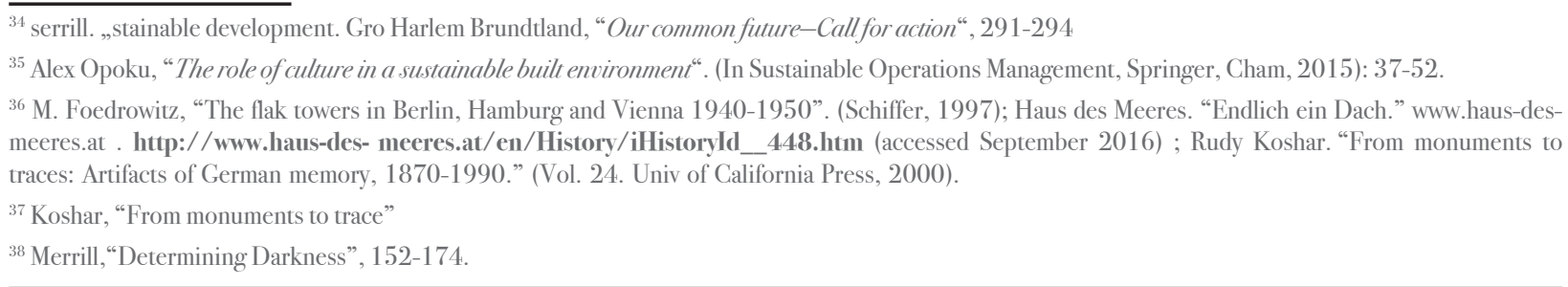


dissimilarities between them, hence a more thorough comparative analysis.

In regards of the 'function' variable; all three cases had relatively close functions; constructed during wartime, they were mainly used for military purposes and anti-raid shelter. However, the new function following the Second World War is the main dissimilarity that is analysed in the research.

The second variable; 'necessity' that demonstrate the need to whether continue or change the original function is also a major similarity between the cases, since currently there is no need for air-raid shelters and military flak towers, the analysis focused on the factors that led to the current use of each case.

As for the last variable; 'scale', since all cases are from the same period and political ideology, and were built in similar circumstances, the scale variable is approximately corresponding.

The similar chronological distance and political ideology were also vital factors in choosing the cases, as Kenneth Foote argued that in order for a community to recognise and deal with unpleasant memories, it has to come to terms with them, and usually that happens in a span of 50 to 150 years. ${ }^{39}$

Therefore, in the chosen cases, the enough temporal proximity of seven decades allows the study of the cases to be held objectively, in addition to a reasonable comparison between them since they all are from the Third Reich era; hence all have relatively similar backgrounds.

Another factor that resulted in choosing those specific cases is their location in the heart of three major cities; Vienna, Hamburg and Berlin, which led to making it crucial to deal with such structure and confront the unpleasantness attached to them as soon as possible.

All of the above-mentioned similarities formed the foundation of which the analysis of the cases started from; however, the dissimilarities are the factors that led to different outcomes.

\section{Haus des Meeres, Vienna}

Located in Esterhàzy park, this Flak tower was a part of a project initiated by Hitler to construct six Flak towers in Berlin, Hamburg and Vienna between 1940 and 1945 for two main purposes; to defend against the Allied air raid and to protect civilians in case of an attack. ${ }^{40}$ As for the other Flak towers in Hamburg and Berlin; the Flak towers in Berlin were demolished by the Allies due to their location in the capital, and one of Hamburg's flak towers is included within this research.

The Haus des Meeres was built with massive dimensions; $47.3 \mathrm{~m}$ high, $31 \mathrm{~m} \mathrm{long}$, $15 \mathrm{~m}$ wide and wall thickness that reached $2.5 \mathrm{~m}^{41}$

In 1956 Haus des Meeres or 'House of the Sea', a non-profit organisation, held a temporary aquarium exhibition in the second and third floors of the Flak tower, and due to its success, it was decided to turn the Flak tower into a permanent aquarium, and currently it welcomes over half a million visitor a year, ${ }^{42}$ in addition to a climbing wall on one of its facades. (Figure 3).

\section{Sustainable Development Contributions}

By going back to the definition of sustainable development; specifically this part:

"A process of change in which the exploitation of resources, the direction of investments... and institutional change are all in harmony and enhance both current and future potential to meet human needs and aspirations". ${ }^{3}$

We can conclude that the adaptive reuse of this building had many positive impacts on the environment and contributed to the sustainability in many ways, such as the eco-systems created in the concrete building, whether it is the vertical aquarium or the tropical section. (Figure $4 \&$ Figure 5)

Furthermore, due to its location in the middle of the city, demolishing the building or even leaving it will affect the environment of the surroundings, therefore reusing the building helped eliminating the waste that could be produced if this massive structure was demolished, in addition to reducing the pollution.

Regarding the economic sustainability, adaptively reusing this Flak tower contributed in great ways, such as:

- In 2004 the zoo welcomed more than 250.000 visitors, placing the zoo as the 14th place on the hit list of Viennese attractions.

\footnotetext{
${ }^{39}$ Kenneth E. Foote, "Shadowed ground: America's landscapes of violence and tragedy". (University of Texas Press, 2003).

${ }^{40}$ Haus des Meeres. "History.” www.haus-des-meeres.at. https://www.haus-des-meeres.at/en/History.htm (accessed September 2016)

${ }^{41}$ Haus des Meeres. "History." www.haus-des-meeres.at

${ }^{42}$ Haus des Meeres personnel (Tour guide) interviewed by Bushra Nabas at Haus des Meeres, Vienna, August 2016

${ }^{43}$ Brundtland. "Our common future"
} 
- In 1998, one of the Flak tower's facades was utilised as a climbing wall, which turned the Flak tower into a major attraction.

- Birthday parties were held at the zoo for kids. ${ }^{44}$

All of these activities guaranteed the renewable economical resources harvest.

As for the cultural sustainability of an uncomfortable heritage site, we must first understand clearly its importance and cultural significance, which can enable us to protect it and maintain its significance for future generations.

In Haus des Meeres, this was achieved in numerous ways, such as:

- APermanent exhibition with 22 panels that explains the history of the Flak tower and its role in the Third Reich era, was opened to the public in 2009. ${ }^{45}$ (Figure 6)

- A Museum with historically accurate re-created command centre with radar and radio devices from the war period, in addition, daily guided tours are offered alongside video presentation with original film and sound recordings of civilians during the Second World War. ${ }^{46}$ (Figure 7)

- An artistic installation in 1991 on the outer sides on the 10th and 11th floors of the tower that says 'ZERSCHMETTERT IN STÜCKE (IM FRIEDEN DER NACHT)' and in English 'SMASHED TO PIECES(INTHESTILLOFTHENIGHT)', is open for numerous competingpersonal interpretation. ${ }^{47}$ (Figure 8)

These actions contributed to the continuation of the Flak tower's cultural significance for future generations.

\section{The Energy Bunker, Hamburg}

Like their counterparts in Vienna, the Hamburg towers were built as a part of the project initiated by Hitler between 1940 and 1945. And similar to the Viennese towers, the Hamburg flak towers were constructed by forced labour as a military battle post, with massive cubic dimensions of $47 \times 47$ metres on a broader base ( $57 \times 57$ metres), with an original height of 42 metres. It also served as a shelter for the civilians in war times. ${ }^{48}$

After the war, the British allies began the process of demilitarising Hamburg, including the de-fortification of the Flak towers, however, the building was too huge and destroying it will inevitably lead to destroying some of the surrounding buildings, therefore only the inside was blown up in order to prevent future use, and the bunker appeared undamaged from the outside, but remained unusable for six decades. ${ }^{49}$ (Figure9)

In 2007, a project to transform the bunker into an 'Energy Bunker' for a future-oriented function had started, and was accessible to the public in mid-2013 as part of the International Building Exhibition in Hamburg.

\section{Sustainable Development Contributions}

The Energy bunker is contributing to the environmental sustainability in various ways, most importantly through the 'The solar shell', spread over the south façade and roof together that provides energy for the surrounding buildings. It is the largest rooftop solar thermal system in Germany geared towards supplying a heat network..$^{50}$ (Figure 10)

Additionally, the bunker utilises the concept of 'Energy mix'; that harness renewable sources of energy through the solar panels and combines heat and energy production in an ancient way. The Energy bunker alone will save 95 percent more CO2 emissions than a conventional energy mix. Over a year, this amounts to 6,600 tonnes of CO2. ${ }^{51}$

As for economic sustainability, the bunker contributes in two aspects, energy production and generating revenues through visitors.

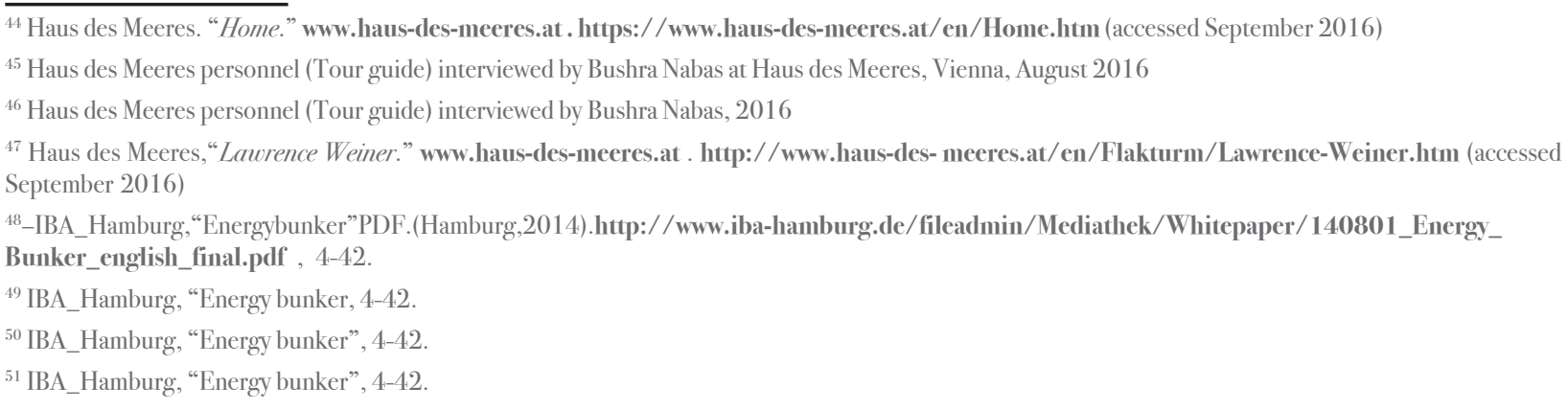


The Energy Bunker is producing power enough to supply a surrounding area of 0.5 square kilometres, containing about 3,000 households. ${ }^{52}$ (Figure 11)

As for the visitors, the bunker received over 100,000 visitors, and currently it is a major visitor attraction, with a cafe, a restaurant and another function room offering space for events and conferences. Nevertheless, since the bunker was not originally constructed for meeting purposes, only a maximum of 200 can be in the building at the same time. ${ }^{53}$ (Figure $12 \&$ Figure 13)

As to the cultural sustainability; in this project, monumental protection was one of the key aspects taken into consideration during the adaptive reuse design, with an abundant of examples; such as the following:

The local community was involved throughout the planning and construction process, hence the adaptive reuse was perceived as a futuristic project, as well as a monument and a memorial. In addition, a programme of events under the title 'Klotz Im Park' was held to exchange precious memories and insights, and to preserve them for present and future generations, this was achieved through meetings between the long-time residents of the surrounding area and last eye-witnesses of the bunker usage during wartime with visitors and youth groups. ${ }^{54}$ Furthermore, attempts to preserve the original concrete façade were not possible due to the poor structural state. Instead, the façade was provided with a solid concrete cladding, and the 'observation windows' are preserved; where portions of the original façade is visible. ${ }^{55}$ (Figure 14)

These events and procedures contributed to the continuation of the Energy bunker's cultural significance for future generations.

\section{Boros Collection, Berlin}

The Reichsbahnbunker or simply The Bunker is an air raid shelter located in Berlin- Mitte, constructed by forced labour in 1942 during the Third Reich to provide a safe place for up to 3,000 people during wartime. ${ }^{56}$

Akin to the previous cases, the bunker's dimensions were massive; $38 \mathrm{~m}$ long and $16 \mathrm{~m}$ high, with a wall thickness that reached twometers. ${ }^{57}$

After the Second World War, the Bunker was reused several times; firstly it was occupied by the Red Army and utilised as a prison in 1945, then four years later in 1949, it was used as a textile warehouse. Later in 1957, the Bunker was converted into a repository for imported tropical fruits from Cuba due to the steady internal temperature, which gave it the name "banana bunker”. After the German Reunification in 1990 and onwards, the different usages of the Bunkers were mainly cultural oriented, such as music parties and art exhibitions. The final stage in the bunker's adaptive reuse journey was in 2003 when Christian Boros purchased the bunker and converted it to house his private contemporary art collection. ${ }^{58}$

\section{Sustainability Development Contributions}

Reusing the bunker immediately after the war instead of demolishing it contributed to the environmental sustainability of the surrounding areas, since demolishing a building with massive structure will result in massive amounts of residue and air pollution. (Figure 15)

Furthermore, the bunker's adaptive reuse contributed to the economic sustainability in a great way, where two exhibitions were held so far for Boros Collection; the first between 2008-2012, attracting 20,000 visitors and over 7,500 tours, and the second one is from 2012 until the present day. ${ }^{59}$ (Figure 16)

Even though the building's façade and its stairwells are protected as historical monuments, the interior walls are not, according

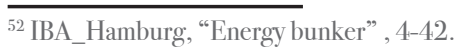

${ }^{53}$ IBA_Hamburg, "Energy bunker”, 4-42.

${ }^{54}$ IBA_Hamburg, “Energy bunker”, 4-42.

${ }^{55}$ IBA_Hamburg, “Energy bunker”, 4-42.

${ }^{56}$ Oliver Basciano, “A Bunker Reborn”. blouinartinfo.com. www.blouinartinfo.com/news/story/270277/a-bunker-reborn (accessed September 2016); Bonatz. "Reichsbahnbunker." architectuul.com http://architectuul.com/architecture/reichsbahnbunker (accessed August 2016); Boros Collection. "Bunker Berlin". sammlung-boros.de https://www.sammlung-boros.de/bunker-berlin.html?L=1 (accessed October 2016)

${ }_{57}$ Magill, "From Nazi Bunker to Artistic Haven." spiegel.de . http://www.spiegel.de/international/zeitgeist/berlin-s-boros-collection-from-nazibunker-to- artistic-haven-a-549487.html (accessed October 2016)

${ }^{58}$ Bonatz, "Reichsbahnbunker." ; Boros Collection, "Bunker Berlin"

${ }^{59}$ Boros Collection, “Exhibition”. sammlung-boros.de https://www.sammlung-boros.de/exhibition.html?L=1 (accessed October 2016);

Tzortzis. "In a Berlin war bunker, Christian Boros creates a showcase for art." nytimes.com . http://www.nytimes.com/2007/06/12/arts/12ihtbunker.1.6105187 .html (accessed October 2016)
} 
to Paolo Stolpmann; an art student who works at the exhibition. ${ }^{60}$ (Figure 17) Therefore, several structural changes have happened to the Bunker; interior walls were modified in order to facilitate the relocation of art pieces, in addition to rectangular shafts that were cut into the walls to enable visitors to look into rooms below, aiming to break up narrow spaces. ${ }^{61}$

Nonetheless, the cultural sustainability was an important aspect in redesigning the interior of the bunker. Due to its design, there is no daylight in the exhibition space, therefore in the conversion process, the architect located windows across from an exposed, ripped-up concrete-and-rebar wall, in order to give the visitor an idea of how reinforced a bunker really is. ${ }^{62}$ Moreover, a penthouse on the top of the building was constructed for private use. ${ }^{63}$

Taking into consideration the history of the building and integrating it in the design process contributed to the continuation of the bunker's cultural significance.

\section{Conclusion}

Despite their relationship to atrocious events, uncomfortable heritage is an important aspect of our history, and helps us confront the challenges of the future by accepting and embracing the unpleasantness of our pasts.

Therefore, adaptively reusing uncomfortable heritage sites is an intricate process; hence many factors affect the final outcomes of it. However, if done properly according to the principles of heritage conservation and the Burra Charter, it can be of great benefit to the sustainable development of any society, whether it is environmental, economic or cultural sustainability.

\section{Bibliography}

Antwi, Stephen Kwadwo, and Kasim Hamza. Qualitative and quantitative research paradigms in business research: A philosophical reflection. European Journal of Business and Management 7, no. 3 (2015).

Ashworth, Gregory J. Heritage, tourism and Europe: A European future for a European past. Heritage, tourism and society (1995).

Basciano, Oliver. A Bunker Reborn. blouinartinfo.com. www.blouinartinfo.com/news/story/270277/a-bunkerreborn (accessed September 2016)

Bonatz. Reichsbahnbunker. architectuul.com http://architectuul.com/architecture/reichsbahnbunker (accessed September 2016)

Boros Collection, Bunker Berlin. sammlung-boros.de https://www.sammlung-boros.de/bunker-berlin.html?L=1 (accessed October 2016)

Boros Collection, Exhibition. sammlung-boros.de https://www.sammlung-boros.de/exhibition.html?L=1 (accessed October 2016)

Ball, Rick. Developers, regeneration and sustainability issues in the reuse of vacant industrial buildings. Building Research \& Information 27, no. 3 (1999).

Benton, Tim, ed. Understanding heritage and memory. Manchester University, (2010).

Brundtland, Gro Harlem. Our common future-Call for action. Environmental Conservation 14, no. 4 (1987).

Bullen, Peter A. Adaptive reuse and sustainability of commercial buildings. Facilities 25, no. 1/2 (2007).

Bullen, Peter A., and Peter ED Love. Adaptive reuse of heritage buildings. Structural Survey 29, no. 5 (2011).

Bullen, Peter A., and Peter ED Love. The rhetoric of adaptive reuse or reality of demolition: Views from the field. Cities 27, no. $4(2010)$.

Carr, Gilly, and Keir Reeves, eds. Heritage and Memory of War: Responses from Small Islands. Vol. 9. Routledge, (2015).

Cassell, Catherine. Qualitative methods in organizational research: A practical guide. Sage Publications Ltd, (1994).

Eddy. Contemporary Art Finds a Shelter in Berlin. nytimes.com . http://www.nytimes.com/2012/09/28/arts/28ihtbunker28.html (accessed September 2016)

Feversham, Polly, and Leo Schmidt. The Berlin Wall Today. Cultural Significance and Conservation Issues. Berlin: Verlag Bauwesen (1999).

Foedrowitz, M. The flak towers in Berlin, Hamburg and Vienna 1940-1950. Schiffer. (1997).

Foote, Kenneth E. Shadowed ground: America's landscapes of violence and tragedy. University of Texas Press. (2003).

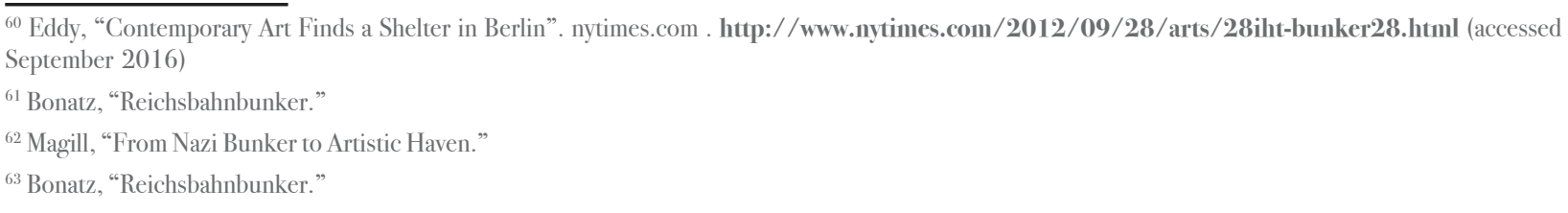


Giddings, Bob, Bill Hopwood, and Geoff O’brien. Environment, economy and society: fitting them together into sustainable development. Sustainable development 10, no. 4 (2002): 187-196

Hopwood, Bill, Mary Mellor, and Geoff O’Brien. Sustainable development: mapping different approaches. Sustainable development 13, no. 1 (2005)

Haus des Meeres. Endlich ein Dach. www.haus-des-meeres.at . http://www.haus-des- meeres.at/en/History/ iHistoryld__448.htm (accessed September 2016)

Haus des Meeres. History. www.haus-des-meeres.at . https://www.haus-des-meeres.at/en/History.htm (accessed September 2016)

Haus des Meeres. Home. www.haus-des-meeres.at . https://www.haus-des-meeres.at/en/Home.htm (accessed September 2016)

Haus des Meeres. Lawrence Weiner. www.haus-des-meeres.at . http://www.haus-des- meeres.at/en/Flakturm/ Lawrence-Weiner.htm (accessed September 2016)

IBA_Hamburg. Energy bunker PDF. Hamburg, 2014. http://www.iba- hamburg.de/fileadmin/Mediathek/ Whitepaper/140801_Energy_Bunker_english_final.pdf

Koshar, Rudy. From monuments to traces: Artifacts of German memory, 1870-1990. Vol. 24. Univ of California Press (2000).

Kristiansen, Kristian. Perspectives on the archaeological heritage: history and future. Archaeological Heritage Management in the Modern World 9 (1989)

Langston, Craig, Francis KW Wong, Eddie CM Hui, and Li-Yin Shen. Strategic assessment of building adaptive reuse opportunities in Hong Kong. Building and Environment 43, no. 10 (2008): 1709-1718.

Logan, William, and Keir Reeves, eds. Places of pain and shame: dealing with 'difficult heritage'. Routledge, (2008).

Lowenthal, David. Tragic traces on the Rhodian shore. Historic Environment 17, no. 1 (2003).

Magill. From Nazi Bunker to Artistic Haven. spiegel.de . http://www.spiegel.de/international/zeitgeist/berlin-s-boroscollection-from-nazi-bunker-to- artistic-haven-a-549487.html (accessed October 2016)

McAtackney, Laura. An Archaeology of the Troubles: the dark heritage of Long Kesh/Maze prison. OUP Oxford, (2014).

Merbach Anjah. Removing Uncomfortable Heritage, its Meaning and Consequence: The Fall of Political Public Monuments in the Former GDR. In A Reader In Uncomfortable Heritage And Dark Tourism, edited by Sam Merrill and Leo Schmidt. Cottbus: BTU Cottbus, (2010): 280, http://www-docs.tu-cottbus.de/denkmalpflege/public/downloads/ UHDT_Reader.pdf

Merrill, Sam “Determining Darkness: The Influence Of Function, Necessity \& Scale On The Memorialisation Of Sensitive Sites". In A Reader In Uncomfortable Heritage And Dark Tourism, edited by Sam Merrill and Leo Schmidt. Cottbus, BTU Cottbus, (2010): 155, http://www-docs.tu-cottbus.de/denkmalpflege/public/downloads/UHDT_ Reader.pdf

Meskell, Lynn. Negative heritage and past mastering in archaeology. Anthropological quarterly 75, no. 3 $(2002)$.

Mörsch, Georg. “Aufgeklärter Widerstand.” Das Denkmal als Frage und Aufgabe, Basel (1989).

Murray, Wendi Field, María Nieves Zedeño, Kacy L. Hollenback, and Calvin Grinnell. The remaking of Lake Sakakawea: Locating cultural viability in negative heritage on the Missouri River. American ethnologist 38, no. 3 (2011).

Opoku, Alex. The role of culture in a sustainable built environment. In Sustainable Operations Management. Springer, Cham, (2015)

Schmidt, Leo. "Architectural conservation: an introduction.” (2008).

Stone, Philip, and Richard Sharpley. "Consuming dark tourism: A thanatological perspective." Annals of tourism Research 35 , no. 2 (2008).

Stone, Philip. A dark tourism spectrum: Towards a typology of death and macabre related tourist sites, attractions and exhibitions. Turizam: međunarodni znanstveno-stručni časopis 54, no. 2 (2006)

Tunbridge, John E., and Gregory John Ashworth. Dissonant heritage: the management of the past as a resource in conflict. John Wiley \& Sons, (1996).

Tzortzis. In a Berlin war bunker, Christian Boros creates a showcase for art. nytimes.com . http://www.nytimes. com/2007/06/12/arts/12iht- bunker.1.6105187 .html (accessed October 2016)

Wilkinson,SaraJ., KimberleyJames, andRichardReed.UsingbuildingadaptationtodeliversustainabilityinAustralia. Structural Survey 27,no. 1(2009).

Yung, Esther HK, and Edwin HW Chan. Implementation challenges to the adaptive reuse of heritage buildings: Towards the goals of sustainable, low carbon cities. Habitat International 36, no. 3 (2012) 


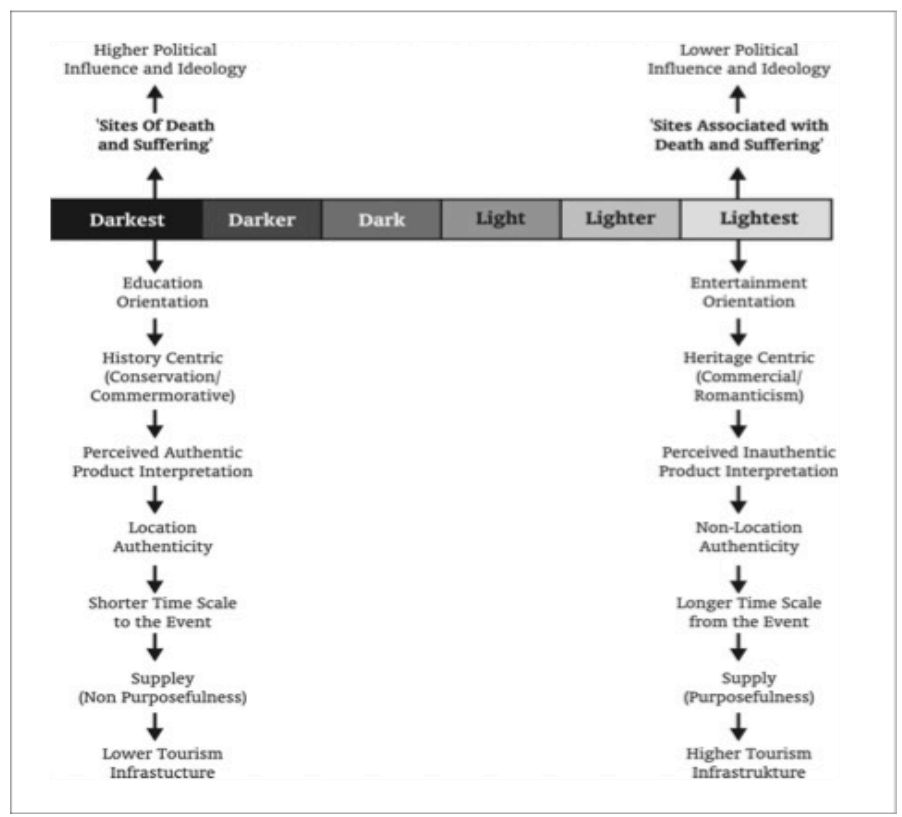

Fig. 1: Stone's Dark Tourism Spectrum

Source: Stone, Philip. A dark tourism spectrum: Towards a typology of death and macabre related tourist sites, attractions and exhibitions. Turizam: međunarodniznanstveno-strućni ćasopis 54, no. 2 (2006).

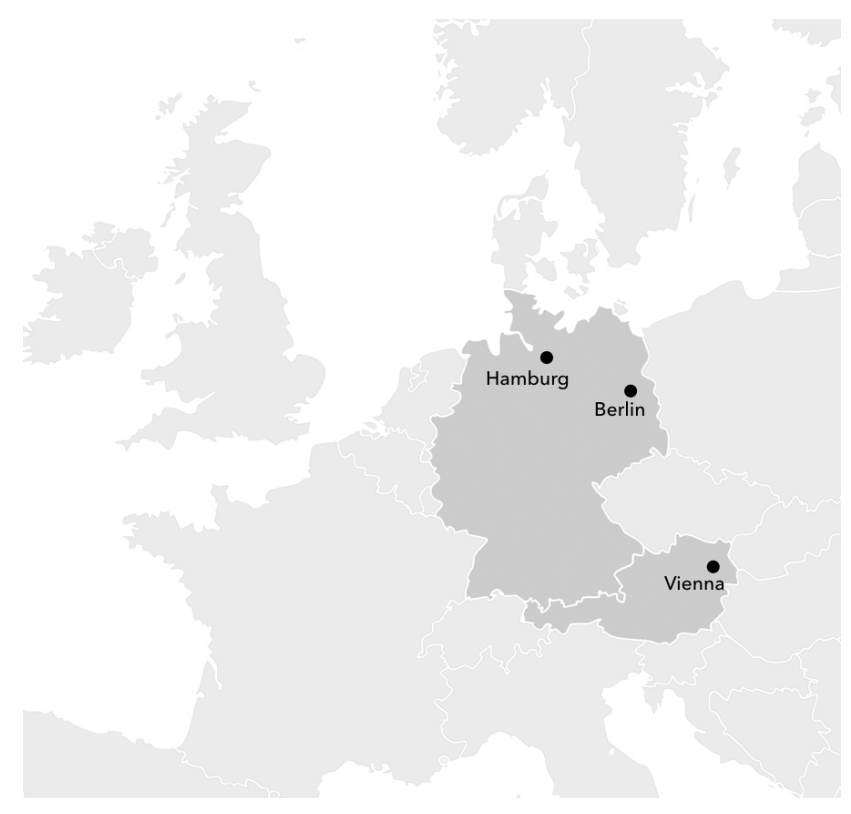

Fig. 2: The case studies 


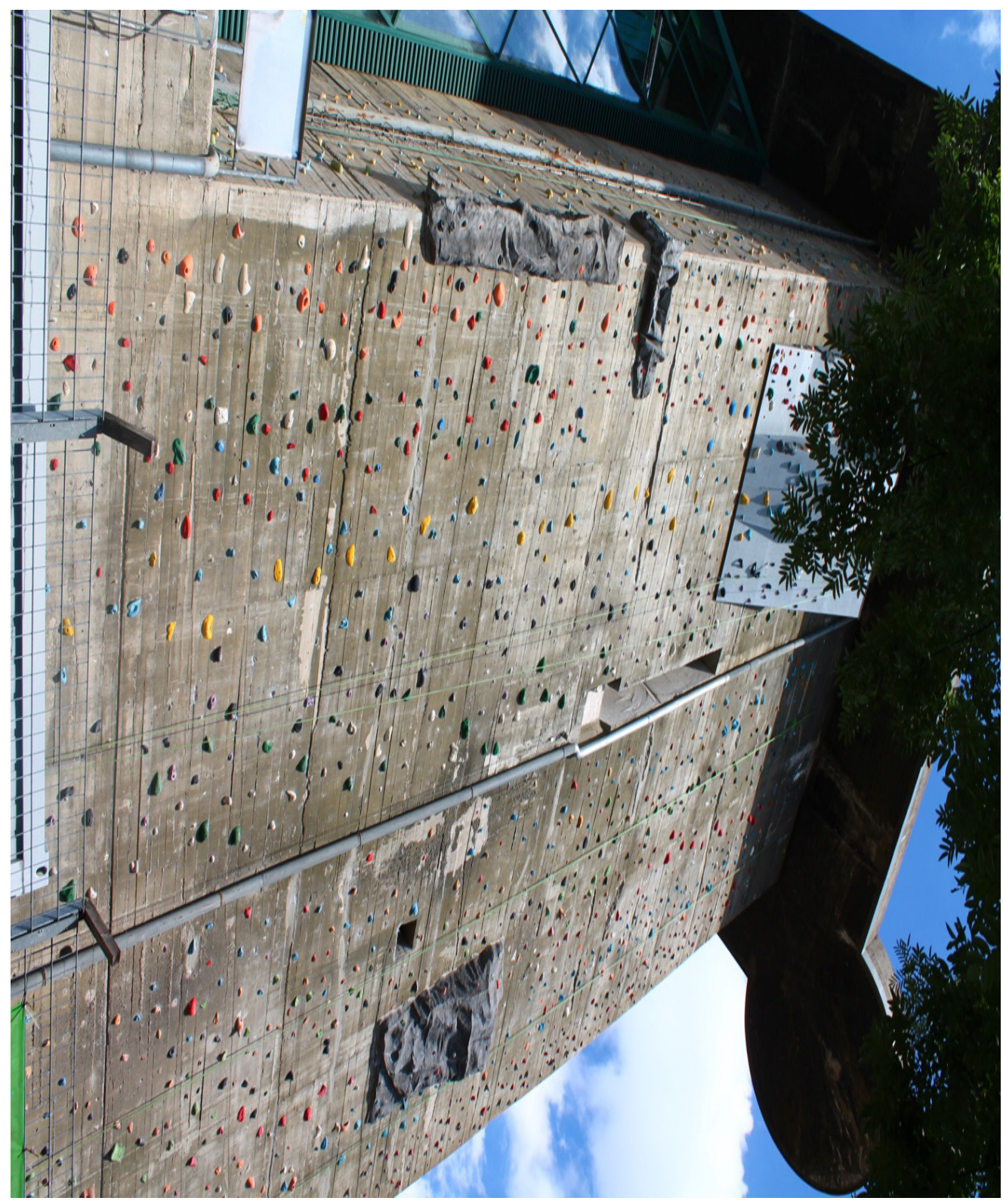

Fig. 3: Climbing wall on Haus des Meeres

Source: Author, 2016 


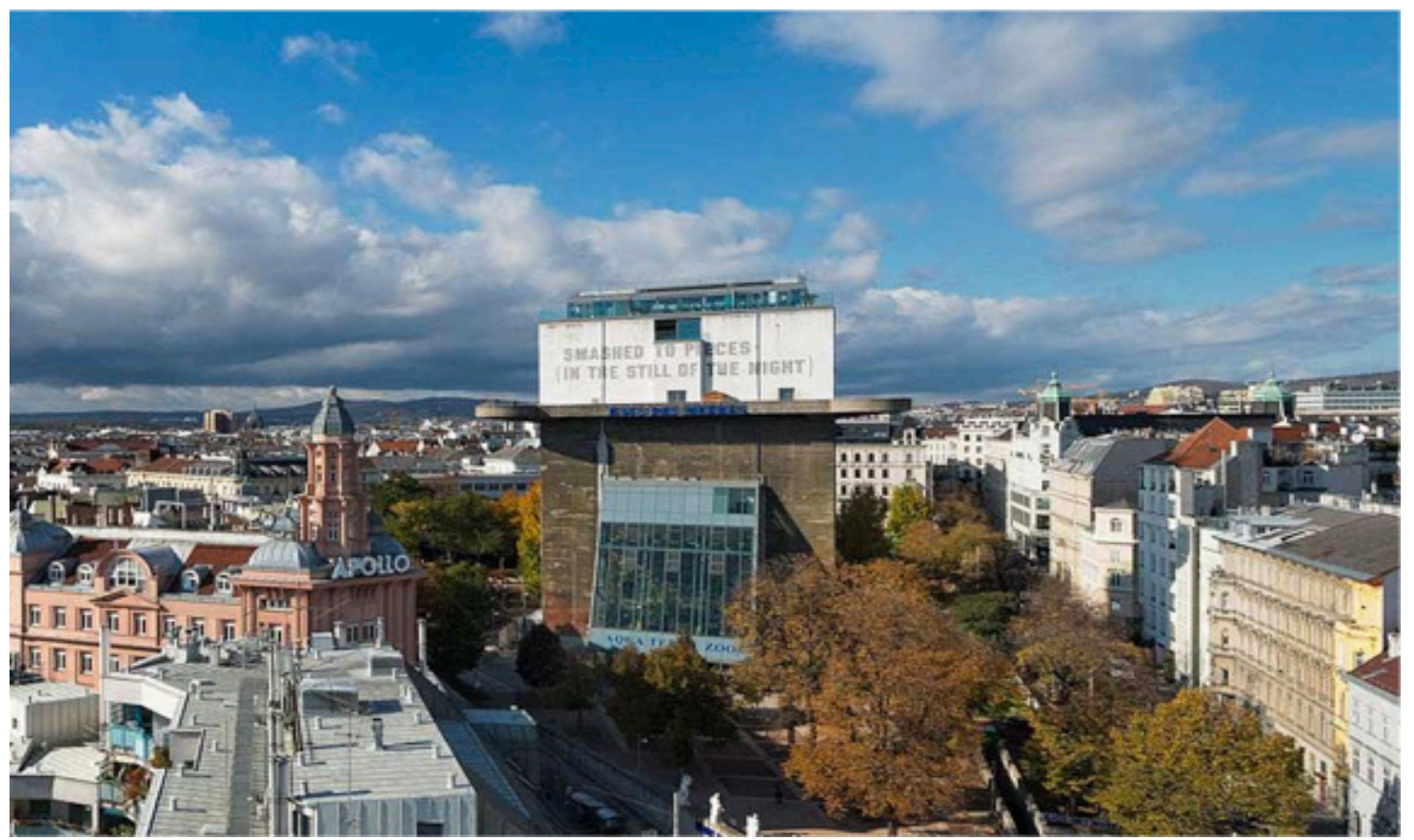

Fig. 4: The massive concrete structure

Source: Author, 2016

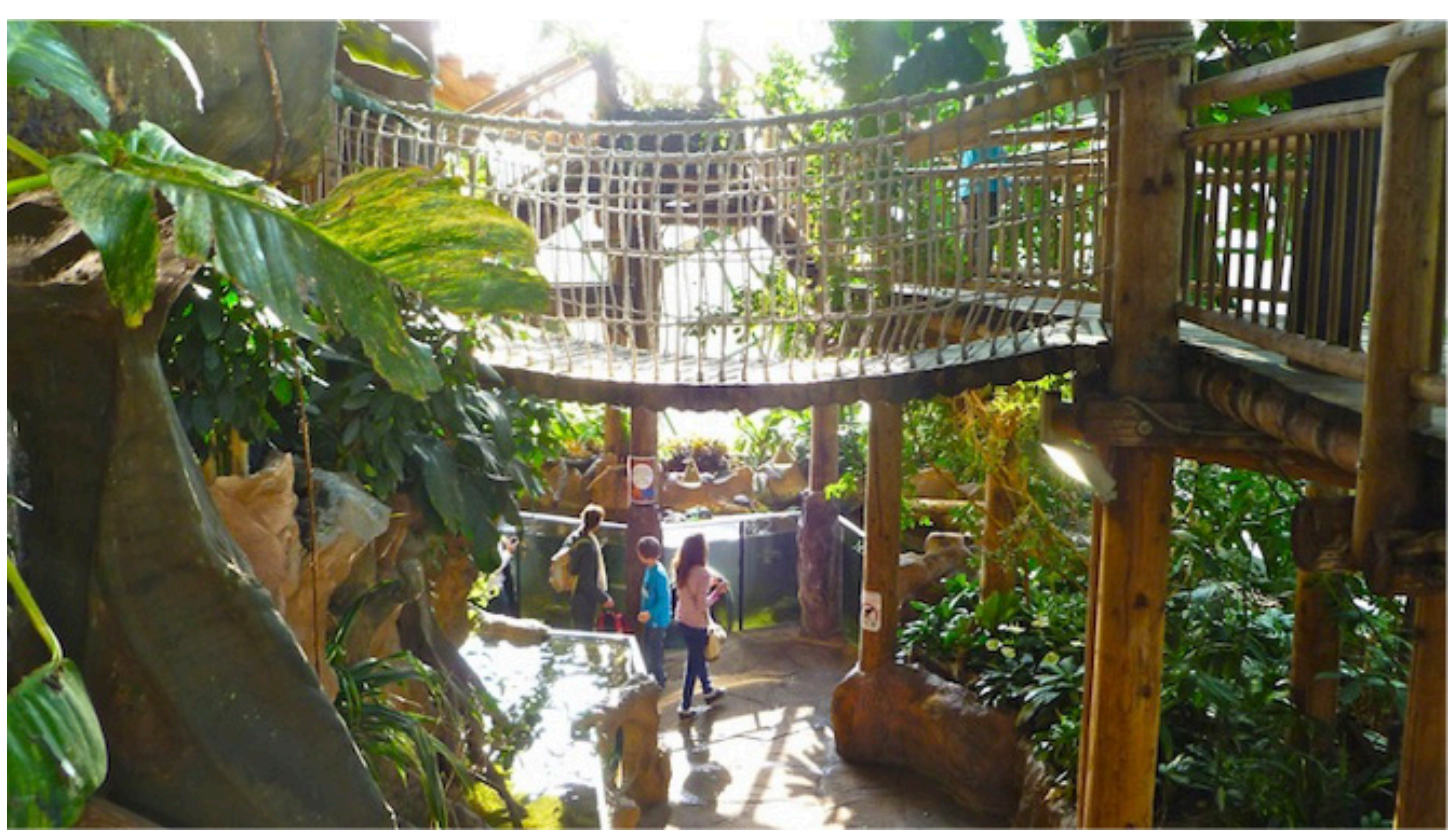

Fig. 5: The Tropical Section

Source: Author, 2016 


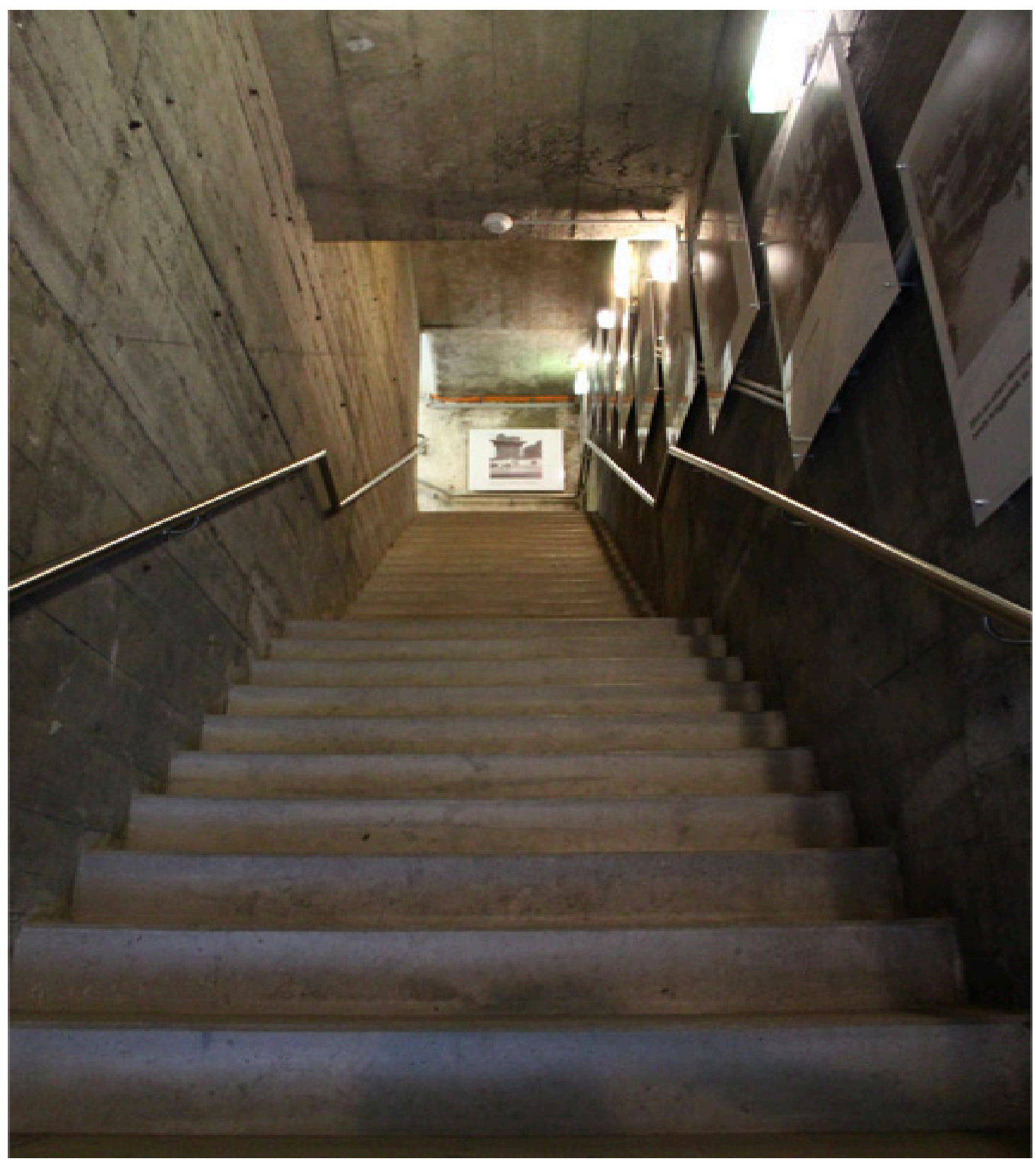

Fig. 6: Exhibition

Source: Author, 2016 


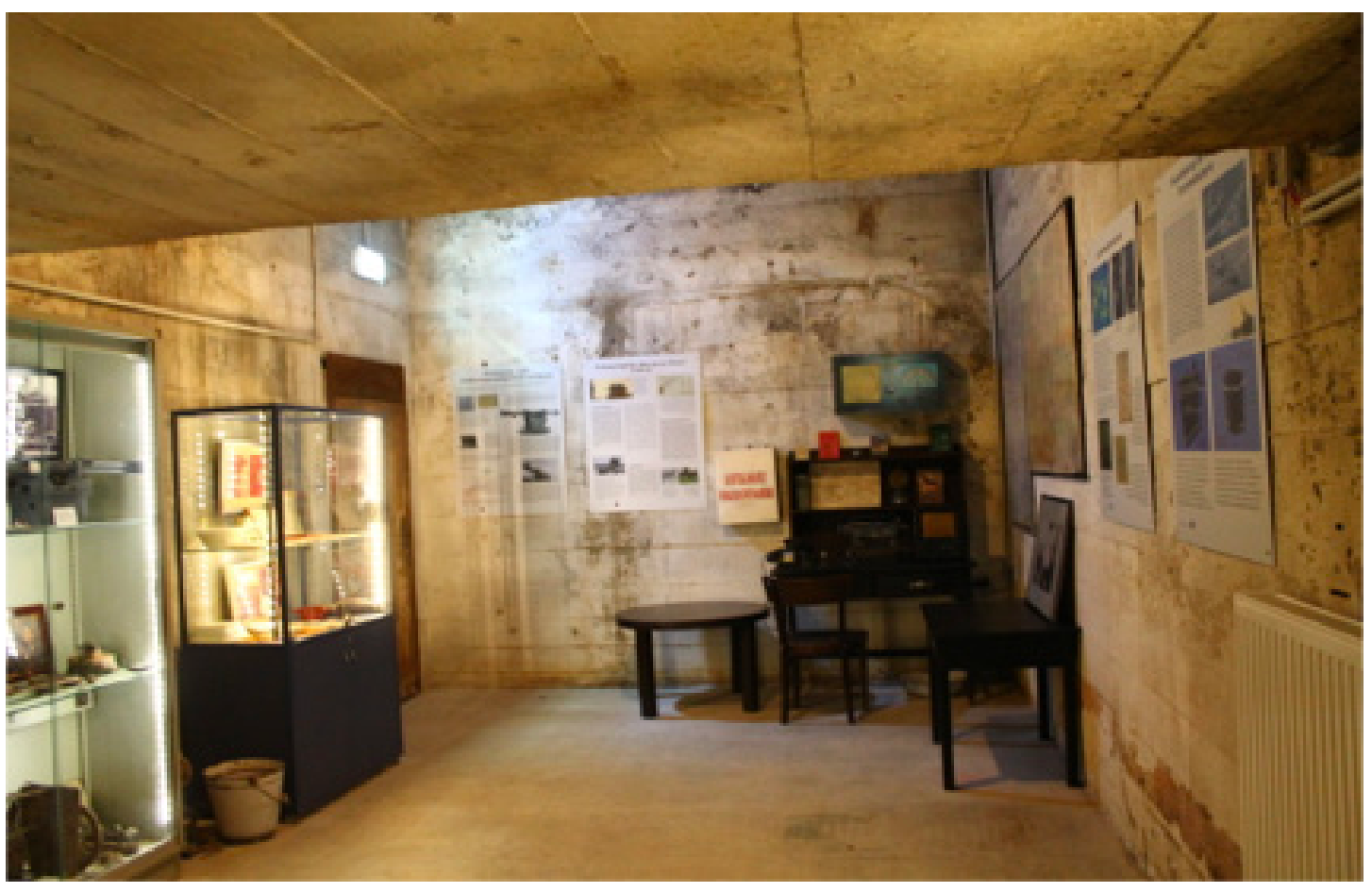

Fig. 7: Museum

Source: Author, 2016

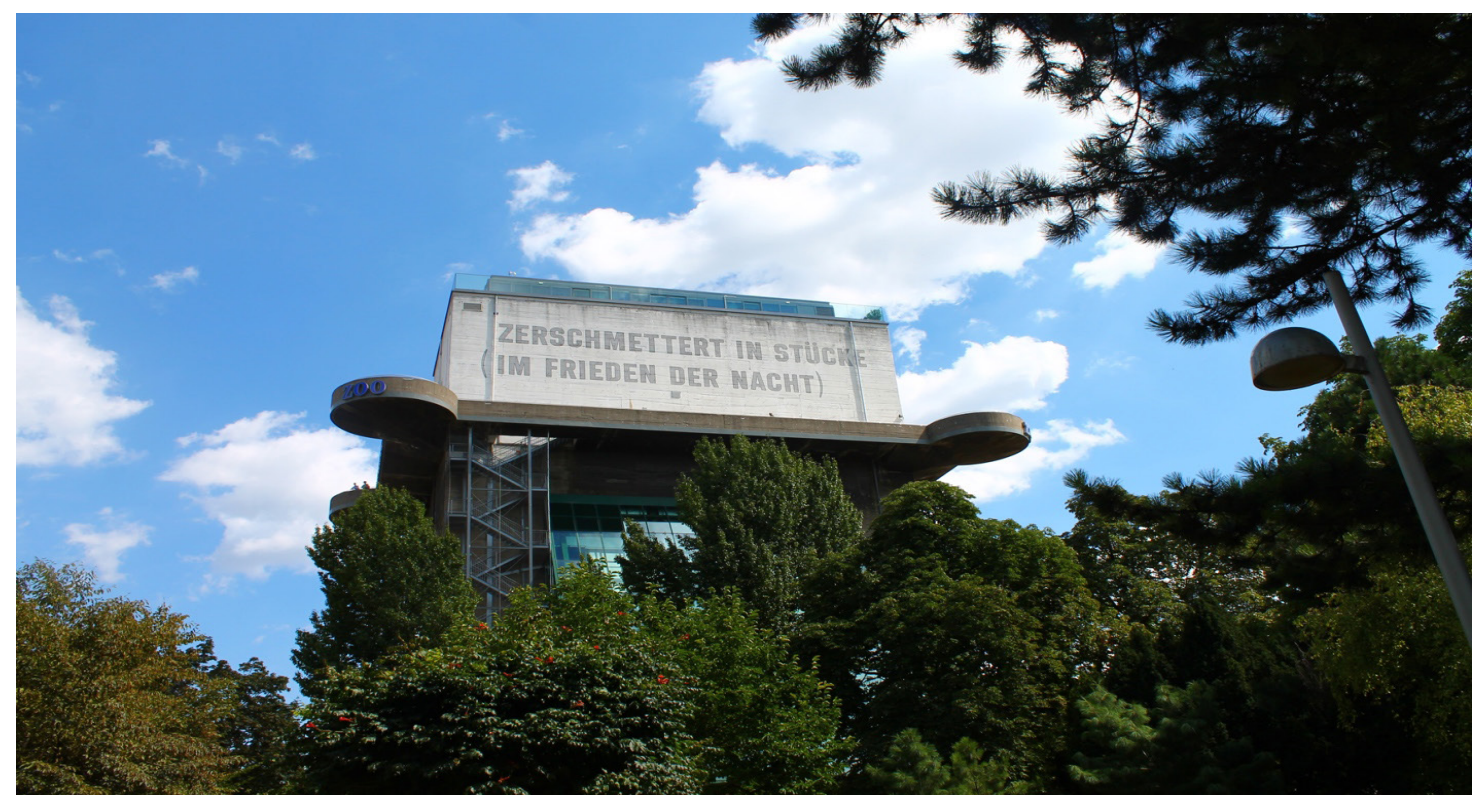

Fig. 8: Artistic Installations

Source: Author, 2016 


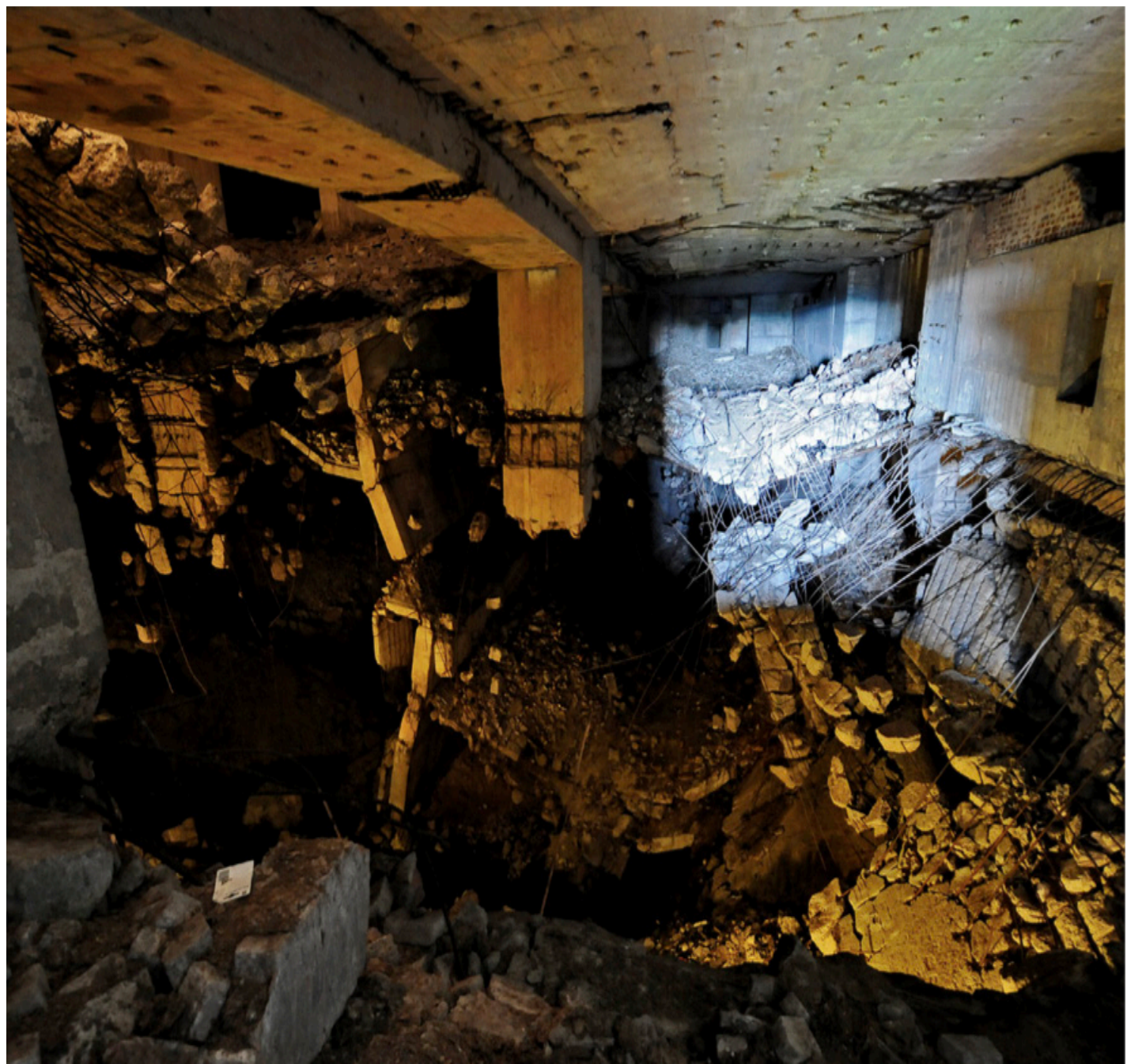

Fig. 9: The damage inside the Bunker

Source: IBA_Hamburg. Energy bunker PDF. Hamburg, 2014. http://www.iba-hamburg.de/fileadmin/Mediathek/Whitepaper/140801_Energy_Bunker_ english final.pdf 


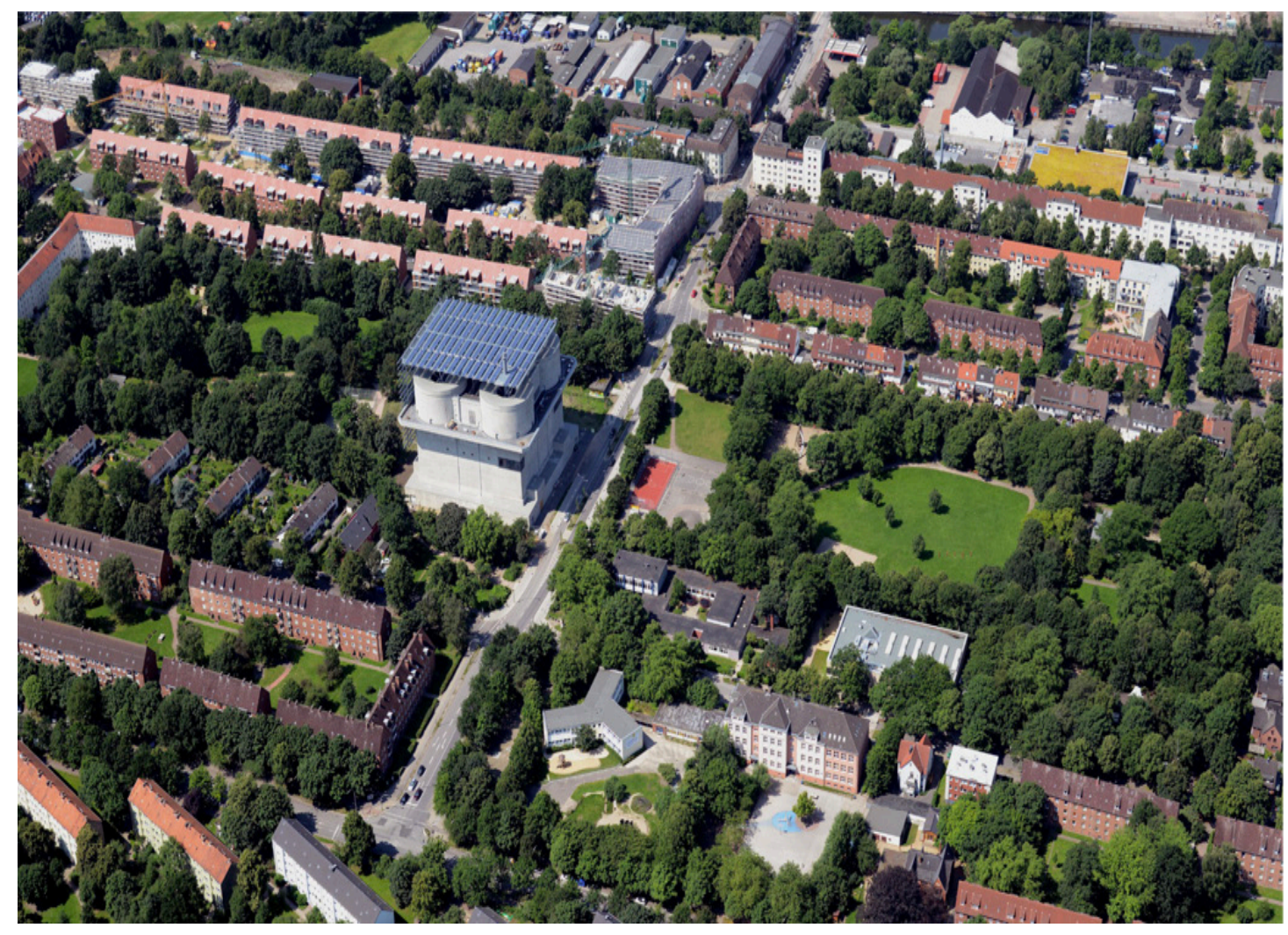

Fig. 10: The solar shell

Source:IBA_Hamburg. Energy bunker PDF. Hamburg, 2014. http://www.iba-hamburg.de/fileadmin/Mediathek/Whitepaper/140801_Energy_Bunker_ english_final.pdf 


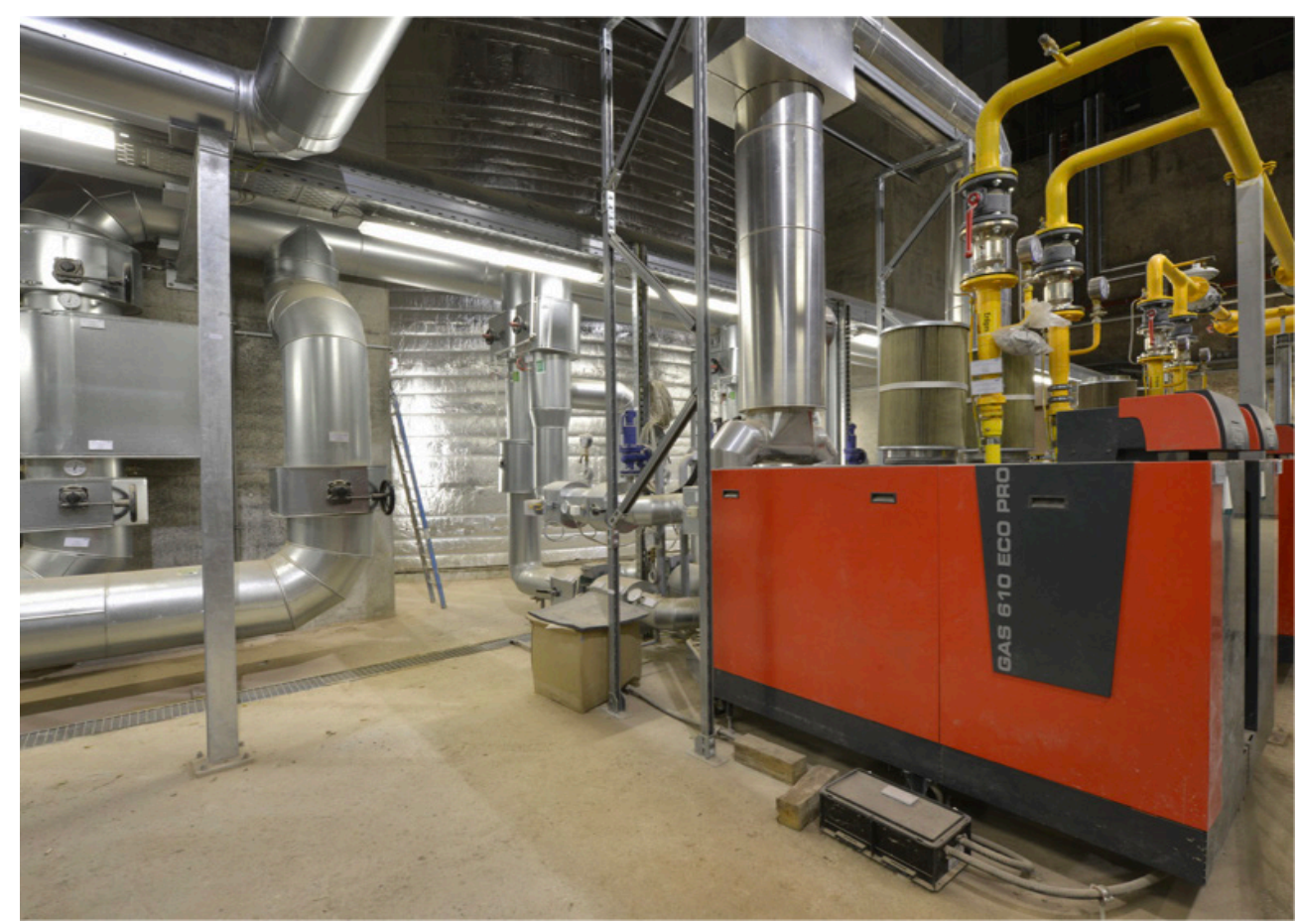

Fig. 11: Energy Production

Source:IBA_Hamburg. Energy bunker PDF. Hamburg, 2014. http://www.iba-hamburg.delfileadmin/Mediathek/Whitepaper/140801_Energy_Bunker_ english_final.pdf 


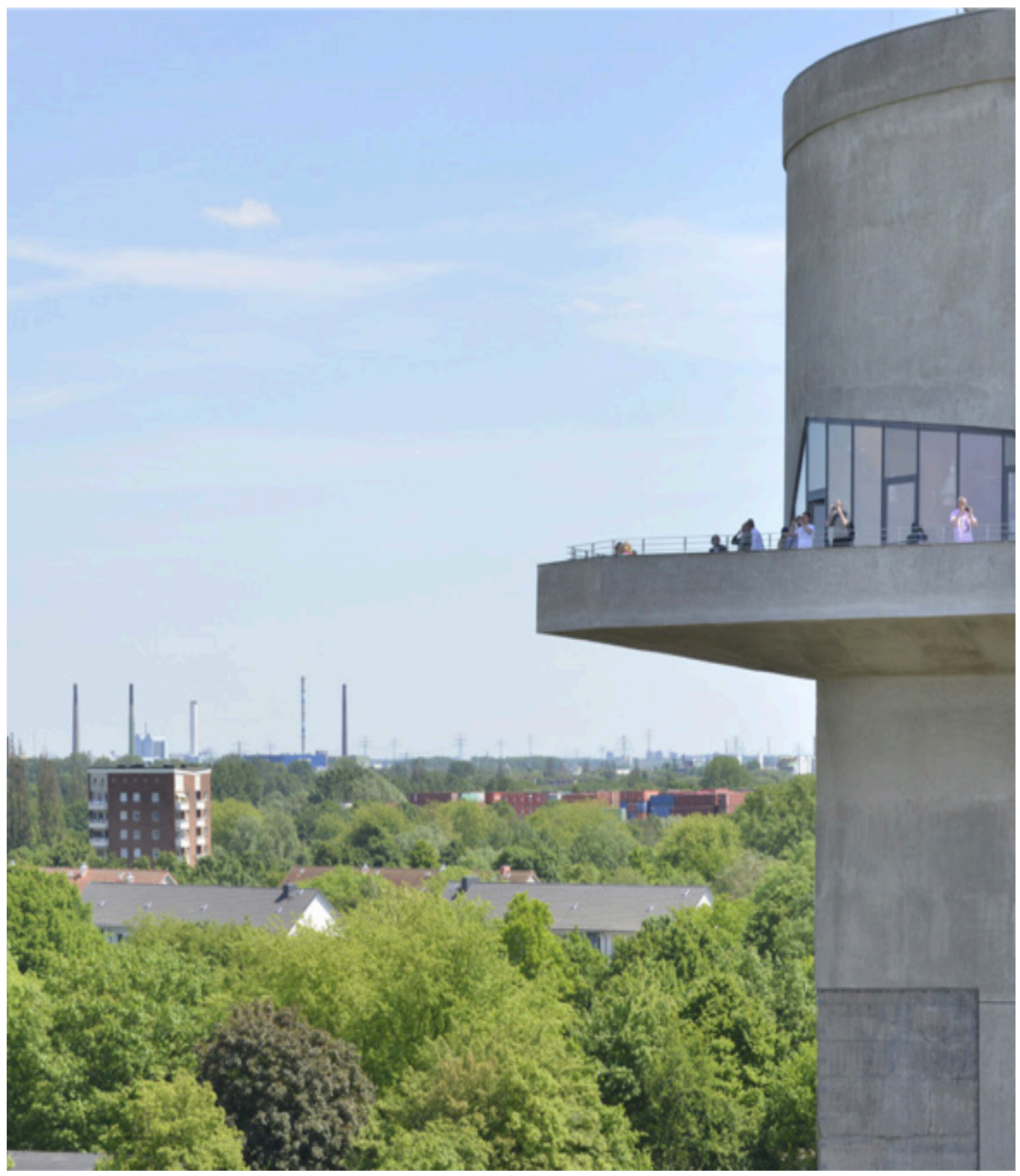

Fig. 12:Café

Source:IBA_Hamburg. Energy bunker PDF. Hamburg, 2014.http://www.iba-hamburg.de/fileadmin/Mediathek/Whitepaper/140801_Energy_Bunker_ english final.pdf 


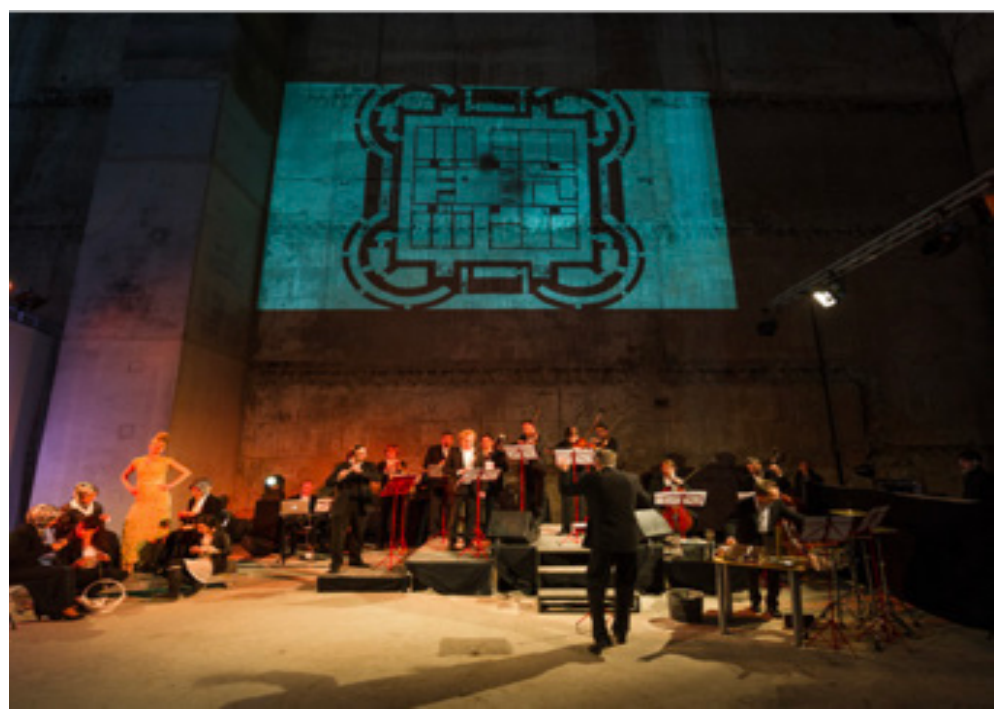

Fig. 13: Visitor area

Source:IBA_Hamburg. Energy bunker PDF. Hamburg, 2014.http://www.iba-hamburg.de/fileadmin/Mediathek/Whitepaper/140801_Energy_Bunker_ english final.pdf

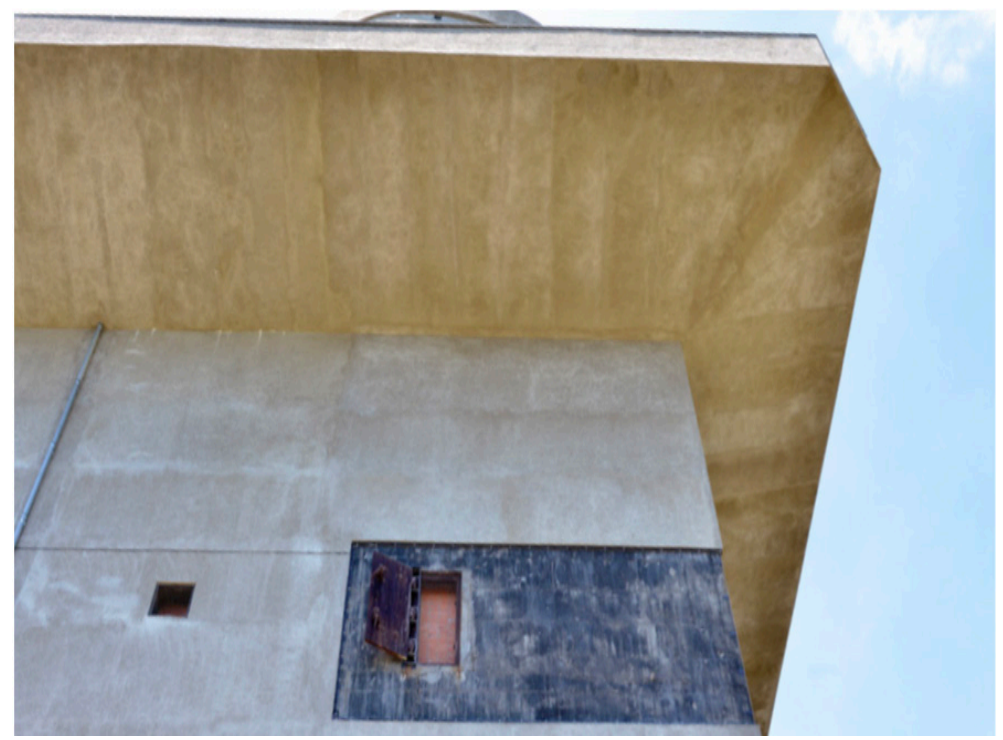

Fig. 14: Observation windows

Source:IBA_Hamburg. Energy bunker PDF. Hamburg, 2014. hitp://www.iba-hamburg.de/fileadmin/Mediathek/Whitepaper/140801_Energy_Bunker english_final.pdf 


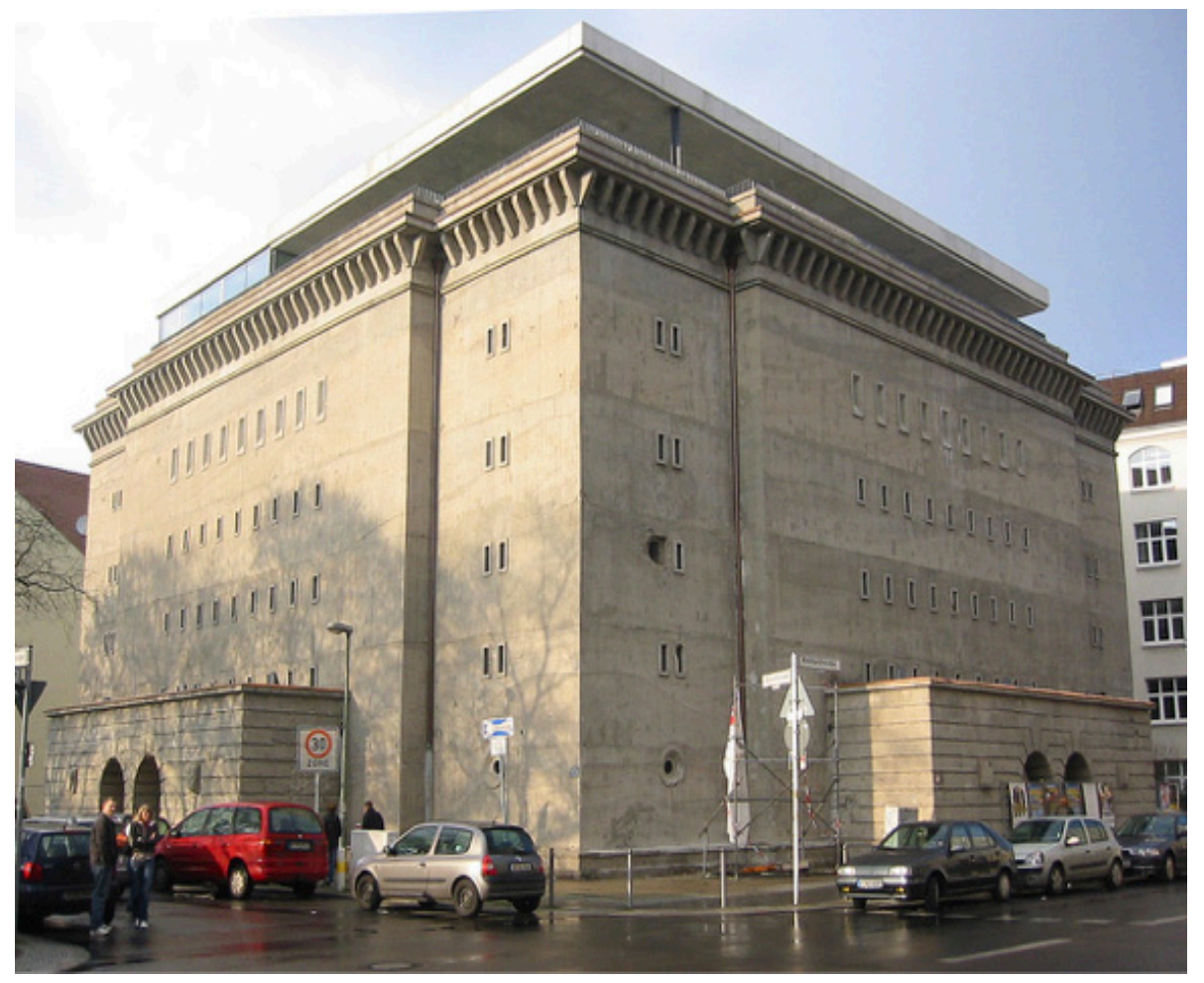

Fig. 15: Berlin Bunker - Borros Collection

Boros Collection, Bunker Berlin. sammlung-boros.de https://www.sammlung-boros.de/bunker-berlin.html?L=1 (accessed October 2016) 


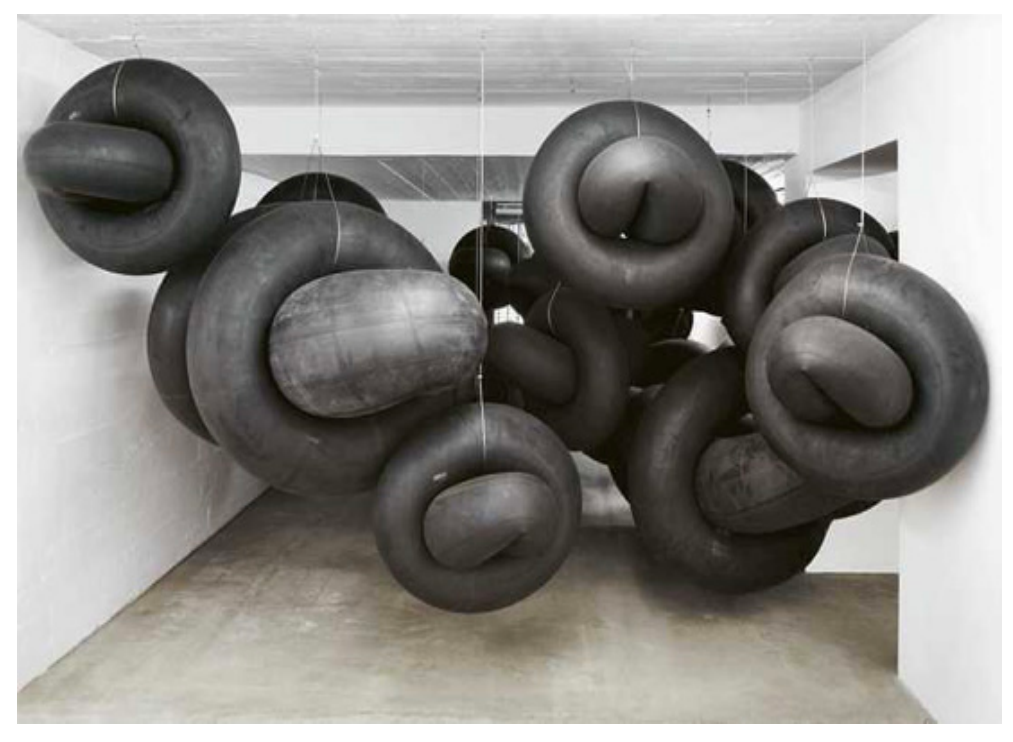

Fig. 16: Modern art installations

Boros Collection, Exhibition. sammlung-boros.de htps://www.sammlung-boros.de/exhibition.html?L=1 (accessed October 2016)

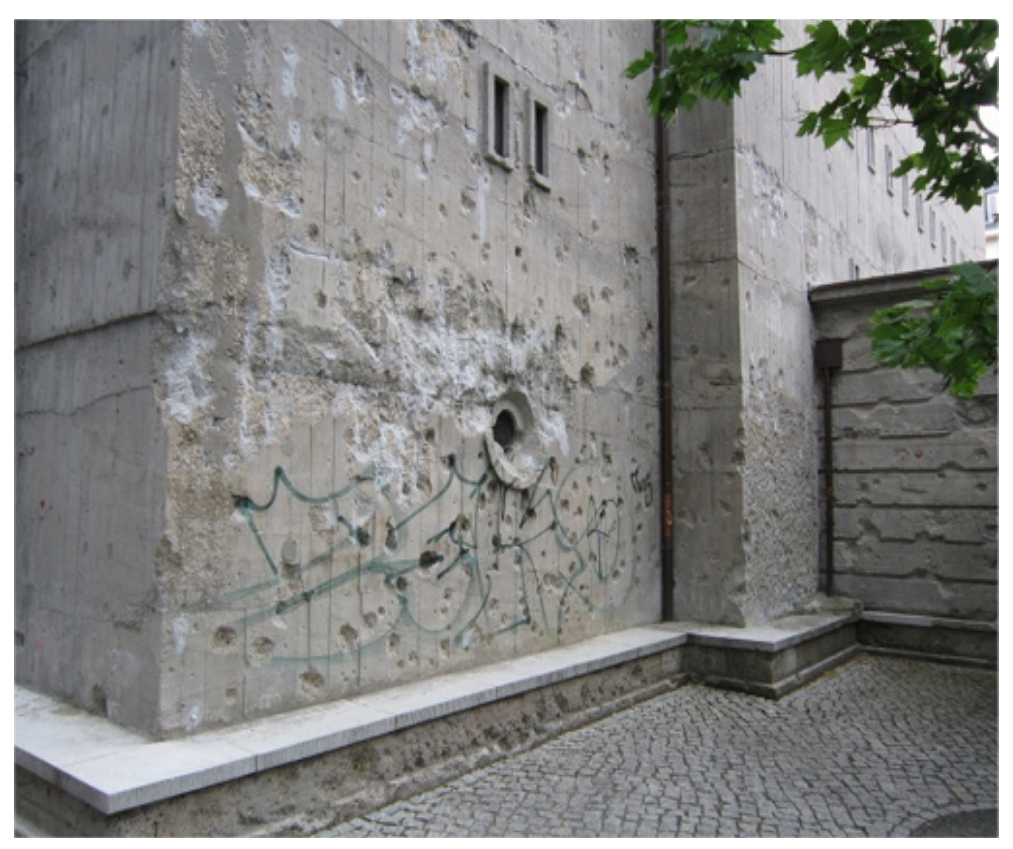

Fig 17: Outerfaçade

Boros Collection, Bunker Berlin. sammlung-boros.de https://www.sammlung-boros.de/bunker-berlin.html?L=1 (accessed October 2016) 